\title{
Maturation of Bovine Oocytes by Co-culture with Rabbit Preovulatory Follicle Cells
}

\author{
Kazuhiro Saeki, Yoshikazu Nagao, Kenji Utaka and \\ Hisao IsHIMORI \\ Embryo Transplantation Laboratory, Snow Brand Milk \\ Products Co., Ltd., Tomakomai-Shi 059-13
}

(Received May 12, 1989)

Key words : bovine, rabbit follicle cells, blastocyst stage

Since the first birth of a calf by a technique of in vitro maturation and fertilization was reported by HANADA et $a l^{1}$, many attempts have been made to produce bovine embryos derived from in vitro matured and fertilized oocytes $^{2-4)}$. Establishment of this technique would lead to mass production of bovine embryos for beef and preparation of early fertilized eggs for biotechnological purposes. However, developmental ability to the morula or blastocyst stage of oocytes matured in vitro was lower ${ }^{5)}$ than that matured in vivo ${ }^{6)}$. CRITSER et $a l^{7)}$ reported that the addition of follicle cells from bovine preovulatory follicles to the medium was very effective to obtain bovine morulae or blastocysts after in vitro fertilization $(0 \%$ and $36 \%$ without and with the cells, respectively).

In this report, effects of inter-species (rabbit) follicle cells to maturation of bovine oocytes in vitro and their subsequent development to blastocysts were described.

\section{Materials and Methods}

Each rabbit was superovulated with $\mathrm{FSH}^{8)}$ or $\mathrm{hMG}^{9)}$. Three hours after the hCG injection, follicle cells were collected and diluted ${ }^{10)}$ with a maturation medium ${ }^{11)}$ at a concentration of $1-2 \times 10^{6}$ cells $/ \mathrm{m} l$.

Bovine oocytes collected from slaughterhouse ovaries were cultured in $50 \mu l$ of the maturation medium (10 oocytes $/ 50 \mu l)$ under paraffin oil with or without the follicle cells for $26-28 \mathrm{~h}$ in a $39^{\circ} \mathrm{C} \mathrm{CO}_{2}$ incubator $\left(5 \% \mathrm{CO}_{2}\right.$ in air, $100 \%$ humidity).

Bovine in vitro fertilization was carried out by the method described previously by IRITANI et $a l^{11)}$. Five hours after insemination, the oocytes were denuded by vortex agitation ${ }^{4)}$ and cultured in $50 \mu l$ of TCM-199 supplemented with $10 \%$ heat-inactivated fetal calf serum (FCS) (10\%-FCS-TCM-199) ${ }^{11)}$ for $12-15 \mathrm{~h}$.

Some of the oocytes were fixed and stained to assess the fertilization ${ }^{12)}$.

The rest of the oocytes were transferred into ligated oviducts of female New Zealand White rabbits caged individually $(3.4-3.7 \mathrm{~kg}$ bodyweight, nullipara) and incubated for 6-7 days for blastulation ${ }^{6,11}$. The recovered eggs were fixed ${ }^{13)}$ immediately or 1 day after cultivation in $10 \%$ FCS-TCM-199, stained with $0.05 \%$ acridine-orange and their nuclei were counted under a fluorescent microscopy.

ウサギ卵胞細胞之の共培養で成熟させたウシ卵胞卵の体外受精後の発育能 : 佐伯和弘・長尾慶和・宇高健二・石 森久雄（雪印乳業(株受精卵移植研究所 苫小牧市植苗 119) 
Table 1. In vitro fertilization and development of bovine oocytes co cultured with rabbit preovulatory follicle cells*

\begin{tabular}{|c|c|c|c|c|c|c|c|}
\hline \multirow{2}{*}{$\begin{array}{l}\text { Co-culture } \\
\text { with } \\
\text { follicle } \\
\text { cells }\end{array}$} & \multicolumn{3}{|c|}{ Fertilization } & \multicolumn{4}{|c|}{ Development in rabbit oviducts } \\
\hline & $\begin{array}{l}\text { No, of } \\
\text { oocytes } \\
\text { examined }\end{array}$ & $\begin{array}{l}\text { No. }(\not 6)^{3} \text { of } \\
\text { oocytes } \\
\text { fertilized }\end{array}$ & $\begin{array}{l}\text { No. }(\%)^{\circ} \text { of } \\
\text { oocytes normally } \\
\text { fertilized }\end{array}$ & $\begin{array}{l}\text { No. of } \\
\text { oocytes } \\
\text { transferred }\end{array}$ & $\begin{array}{l}\text { No. }(96) \text { of } \\
\text { embryos } \\
\text { recovered }\end{array}$ & $\begin{array}{l}\text { No. }(96)^{c} \text { of } \\
\text { blasto- }^{-} \\
\text {cysts }^{d}\end{array}$ & $\begin{array}{l}\text { Mean number of } \\
\text { nuclei in } \\
\text { blastocysts } \pm S D\end{array}$ \\
\hline+ & 35 & $28(80)$ & $23(66)$ & 117 & $55(47)$ & $17(31)$ & $121 \pm 30$ \\
\hline- (control) & 42 & $38(90)$ & $30(71)$ & 100 & $69(69)$ & $9(13)$ & $114 \pm 46$ \\
\hline
\end{tabular}

* : Data were pooled over four replicates

: Percentages of the total number of oocytes examined

b : Monospermic oocytes with male and female pronuclei

c : Percentages of the total number of embryos recovered

$\checkmark$ : Significant difference $(P<0.05)$ between treatments

\section{Results}

The results were summarized in Table 1. There were no significant differences in total fertilization as well as normal. However, the rate of blastocysts increased significantly $(\mathrm{P}<$ 0.05 ) by an addition of rabbit follicle cells. No significant difference of number of nuclei in blastocysts were observed.

\section{Discussion}

To our knowledge, this is the first demonstration that the co-culture with the inter-species (rabbit) follicle cells at bovine oocyte maturation enhanced the developmental ability of the oocytes after in vitro fertilization. However, the proportion of developed embryos in the present study $(31 \%)$ are lower than those reported by Lu et $a l^{2)}(78 \%)$ and Xu et $a l^{3)}$ (38 $\%$ ), who used the co-culture system with bovine follicle cells collected from the slaughterhouse ovaries and $20 \%$ serum from estrus cows as protein supplement, and did not add hormones to the maturation medium. The success rate presented here are also slightly lower than that reported by CRITSER et $a l^{7)}$ (36\%) using the coculture system with the follicle cells from bovine preovulatory follicle.

Since the mean number of nuclei of the blastocysts in the present study was almost same as that of day 7 bovine blastocysts (135 \pm 42 , unpublished data), it seems that the blastocysts derived from the oocytes matured and fertilized in vitro were normal.

\section{References}

1) Hanada, A., Y. Enya and T. SuzukI, Proc. 78th Meeting of the Jap. Soc. Zootech. Sci., I-35: 18. 1986.

2) Lu K.H., I. Gordon, M. Gallagher and $H$. MCGovern, Vet. Rec., $121: 259-260.1987$.

3) XU K.P., T. Greve, H. Callesen and P. HytTel, J. Reprod. Fert., 81 : 501-504. 1987.

4) Sirard M.A., J.J. Parrish, C.B. Ware, M.L. Leibfried-Rutledge and N.L. First, Biol. Reprod, 39 : 546-552. 1988.

5) Utsumi, K.: H. Katoh and A. Iritani, Theriogenology, 29: 320. 1988.

6) Sirard M.A., R.D. Lambert, D.P. Menard and M. BEDOYA, J. Reprod. Fert., 75 : 551-556. 1985.

7) Critser E.S., M.L. Leibfried-Rutledge, W.H. Eyestone, D.L. NORTHEY and N.L. First, Theriogenology, $25: 150.1986$.

8) Ishibashi, Y, and Y. SAKuma, Methods of mammalian developmental engineering. (SUcA WARA S. ed.), 75-85. Academic Press Center, Tokyo. 1986.

9) Sankai T., K. Tanimoto, K. Kanayama, T. Endo And Y. Sakuma, Jpn. J. Fertil. Steril., 33: 680-681. 1988.

10) Motlik, J. and J. Fulka, J, Reprod. Fert., 63 : 425429. 1981.

11) Iritani A, K. Utsumi, M. Miyake, Y. Hosol and $\mathrm{K}$. SAEKI, In vitro fertilization and other assisted reproduction. (JONES Jr. H.W. and SChrader C. eds.), 583-590. The New York Academy of Sciences, New York, 1988.

12) Iritani A., K. Kasai, K. Niwa and H.B. Song, J. Reprod. Fert., 70 : 487-492. 1984.

13) Mıкамо K., Clinical Gynec. Obstet.: $31:$ 1137-1141. 1977. 